\title{
Public preference towards the integration of krl and transjakarta tariff
}

\author{
Andyka Kusuma , Tri Tjahjono and Alviana Dwi Syaputri \\ Civil Engineering Department, Universitas Indonesia, Depok, Indonesia
}

\begin{abstract}
Transportation costs in Jakarta reach $30 \%$ of the total income of the community every month while the standard that has been set by World Bank is only $10 \%$. This paper discusses the result of willingness-to-pay study conducted at Sudirman railway station in the downtown of Jakarta with the purpose of reducing transportation cost by implementing the tariff integration system of KRL and Transjakarta. The data was collected by the methods of stated preference survey with commuters as the respondent.The survey was conducted by asking the respondents some questions including respondents' socio-economic characteristic, travel distance, and travel choice exercise. The existing modes that will be compared are motorcycle and bus (kopaja). Motorcycle is the mode whom commuters mostly use with $62 \%$ while kopaja is only $38 \%$. The data was analyzed by using discrete choice model and utility function. Based on the analysis, parameters that influence commuters to shift from existing modes to transjakarta are saving time, saving fare, transportation expenditure, and education level. Moreover, the study found that the cheaper the integration tariff offered, the greater the probability of choosing transjakarta services and the faster the travel time of Transjakarta, the greater the probability of choosing transjakarta. Furthermore, each comparison mode has different tariff preferences on the tariff integration system of Transjakarta and KRL.
\end{abstract}

\section{Introduction}

Jakarta as the capital city of Indonesia with more than 10 million populations. This situation creates high demand of transportation in Jakarta. The demand is not only generated by people in Jakarta but also from the suburban area around Jakarta which called BODETABEK. According to Badan Pusat Statistik in 2014 there are 1.38 million commuters from BODETABEK come to Jakarta each day.

Considering the high demand of transportation, Jakarta is now developing and improving the public transportation system. The revamping was started in 2004 where Bus Rapid Transit (Transjakarta) operated and followed with the revitalization of electric railway (KRL) IN 2012. Unfortunately, however some revitalization has been conducted by the government, $70 \%$ of commuters still use the private vehicle.

This high mobility of people in Jakarta using private vehicle or public transportation has an impact to the transportation costs they spend everyday. Based on Indonesian Transportation Society (MTI), transportation costs in Jakarta reach $30 \%$ of total community income every month. It is three times higher than the standard that has been set by World Bank which is only $10 \%$. It caused by the lack of integration in every aspect of public transportation system. This problem should be addressed by implementing the system that allow people to cap their transportation costs a day.

Based on this problem, this research aims to observe public preference about how much they willing to pay in a day to use public transportation, in the case of the integration of KRL and transjakarta tariffs.

\section{Literature review}

\subsection{Tariff Integration}

Various study found in observing about public transportation integration. There are three components in transit integration, physical integration, service and operational integration, and payment integration (Setijowarno, 2016). Physical integration can be defined as modal shifting infrastructure that allows passengers to move intra or to other modes easily. Service and operational integration is a well-informed schedule of arrival and departure of public transportation. This integration also reducing passengers' waiting time. While payment integration is the concept of smartcard use which allows an effective and efficient service network. Moreover, one of the most important aspect in public transportation integration is the tariff integration.

Tariff integration can be interpreted as the same pricing scheme from different public transport operators, for example some bus companies apply the same rate for a single trip or some train companies apply the same rate for a certain distance trip. In the wider integration, this same tariff scheme applies even to more than one operator service which means that fares for travel within a certain distance will be the same whether one uses the services of one operator or mixes them with the services 
of different operators. In developed countries the concept of tariff integration is applied by combining fixed tariffs in which they sell valid tickets for an unlimited number of modes including subway, tram and bus with different operators within a specified time period, for instance in one day (Takahashi, 2016).

Summarizing many case studies relate with tariff integration particularly in developed countries, (Abrate et al, 2009) estimated that the tariff integration system in Italy could increase the number of passengers' trip by $2.2 \%$ in the short trip and $12 \%$ in the long trip. (Matas, 2004) estimated that the introduction of the tariff integration system in Madrid in 1987 led to a growth in bus of $3.4 \%$ and underground patronage of $5.3 \%$ in shortrun while bus grew $7 \%$ and underground patronage $15 \%$ in long-run. (Taylor and Carter,1998) stated in Maryland the tariff integration system replaced a five-zone fare structure with a flat fare. The $1 \%$ annual decline in transit ridership shifted to $4 \%$ growth per annum. While in New York the tariff integration system which was introduced in 1994 and 1999 increased weekday ridership by more than $12 \%$ on the subway and by more than $40 \%$ on the bus. (Shiftan \& Sharaby, 2012) concluded from the survey and model that fare is the significant factor in attracting passenger.

\subsection{Jakarta case study}

Jakarta is the most populated city in Indonesia and has high demand of transportation. Based on Department of Transportation, in 2010 the total trips in Jakarta reach 21.9 million trips per day where 15.3 trips are by private vehicles. This condition creates bad traffic particularly in rush hours. Revitalization of public transportation system has been done in order to facilitate the citizen to shift from private to public transportation.

The first modern public transportation in Jakarta was Bus Rapid Transit (BRT) called Transjakarta. This BRT was the first BRT in Southeast Asia. Transjakarta is a BRT system with the longest track in the world with a total length of $208 \mathrm{~km}$ in 13 corridors. Transjakarta mostly operated from 5 a.m to 10 p.m but now some corridors operate 24 hours.

Transjakarta is one of the favorite public transportation in Jakarta. Based on Badan Pusat Statistik (BPS), in 2011 Transjakarta reach the peak of its passenger number $114,769,431$ but it declined to 111,260 , 869 passengers in 2012. The increase started again in 2013 with 112,522,638 passengers, unfortunately in 2015 the decline was higher than before because it can only reach 102,950,384 passengers. While in 2016 the passengers increase again for $20 \%$.

Since 2013, the ticketing system for Transjakarta started to use the electronic ticket system or e-ticket. The type of smartcard that can be used in Transjakarta is issued by several banks such as Bank Rakyat Indonesie (BRIZZI), Bank Central Asia (Flazz), Bank Negara Indonesia (TapCash), Bank Mandiri (e-money), Bank DKI (JakCard), dan Bank Mega (Mega Card).

Tariff for Transjakarta is divided into two types, the tariff from 5 a.m to 7 a.m is Rp 2000,- while the the tariff for 7 a.m to 5 a.m is Rp 3500,-. This tariff is already subsidized by the government of Jakarta. The other favorite public transportation in Jakarta is the electric rail called KRL Commuter Line. KRL has been operating since 1925 and now KRL's routes serve to the sub-urban area of Jakarta such as Bogor, Tangerang, Depok, Bekasi, and Serpong. Based on PT. Kereta Commuter Indonesia (KCI), till August $2017 \mathrm{KRL}$ has covered 72 stations throughout Jabodetabek, Banten, and Cikarang with the length of route $418.5 \mathrm{Km}$.

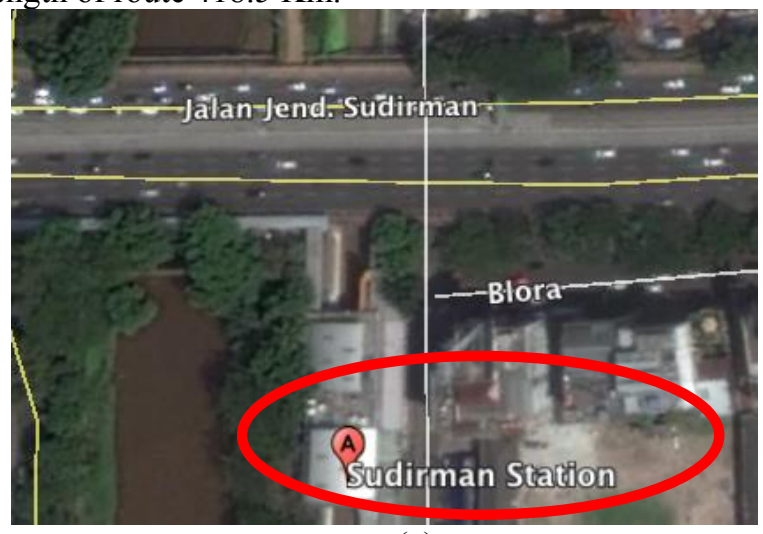

(a)

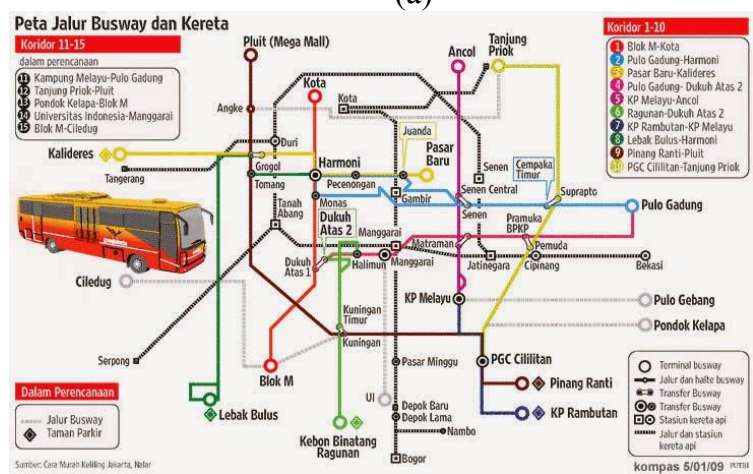

(b)

Figure 1. (a) Sudirman Station from Google Maps and (b) Route Maps of KRL and Transjakarta

Table 1. Number of KRL's passengers per year

\begin{tabular}{|c|c|}
\hline Year & Percentage \\
\hline 2011 & 121.1 Million \\
\hline 2012 & 134.1 Million \\
\hline 2013 & 158.5 Million \\
\hline 2014 & 208.5 Million \\
\hline 2015 & 257.5 Million \\
\hline 2016 & 280.6 Million \\
\hline
\end{tabular}

\subsection{Discrete choice model}

Discrete choice model is a model where the function is used to find the probability of an individual to determine a choice of some alternatives based on socio-economic characteristics and the relative attractiveness of an options (Ortuzar W., 2011). The discrete choice applications in transportation research field are to find the individual transport mode choice for a particular condition. This model will represent the decision making of an individual to choose the mode through a function called Utility Function. The utility function is specified as follows: 


$$
U_{i}=\beta_{0}+\beta_{1} X_{1}+\beta_{2} X_{2} \ldots \beta_{n} X_{n}
$$

where $U_{j}$ is utility of i-choice, $X_{i} \ldots X_{n}$ is the product variables observed, $\beta_{0}$ is the alternative specific constant (ASC) and $\beta_{1}-\beta_{n}$ is the coefficient of variables. The choice in this study is binary where the respondents face two alternatives. In this case, the binomial logit model is used to compare between two modes of transportation. The binomial logit can be written as follows:

$$
\mathrm{P}=\frac{1}{1+e^{-\left(Z_{2}-Z_{1}\right)}}
$$

where the $\mathrm{P}$ is the probability of individu to choose the specific transportation mode while $Z_{1}$ and $Z_{2}$ are considered as the utility function of each alternatives mode.

\section{Methodology}

The following analysis of the public's preference on tariff integration of KRL and Transjakarta is based on various data sources. The data is divided into two, the primary data and secondary data.

\subsection{Primary data}

The primary data is based on stated-preference survey conducted in Sudirman Station. Stated preference survey aims to validate public's preference to shift from the existing mode to Transjakarta. This survey will show the potential additional demand of Transjakarta and the preference tariff people willing to pay.

In this survey, the respondent is the commuter that travel the main trip use KRL and use motorcycle or conventional bus on their last mile trip. The survey conducted in Sudirman Station where the people in weekdays mostly ended their main trip to work.

\subsection{Secondary data}

The secondary data is the additional data that was obtained through some books, journal, or paper. This data will be used to support the primary data collection. The secondary data for this research is as follows:

1. The distance from Sudirman Station to some sub-urban area within a certain radius.

2. Transportation cost per week.

3. Travel time for KRL, Transjakarta, motorcycle, and the conventional bus within a certain radius.

\subsection{The model}

The model is based on stated-preference survey, asking the respondents how much they willing to pay if the tariff of KRL and Transjakarta are integrated and would they shift to use Transjakarta. There are two alternatives asked to the respondent and their response should be yes or no.

The model is specified as a binomial logit model and based on discrete choice model. The utility function in this study using combination among four variables. There are two measured components and two socio-economic variables. The measured components are the different between existing fare of transjakarta and other modes (saving fare) and the travel time different between transjakarta and other modes (saving time). The other socio-economic variables are expenditure of transportation and education. In general, the utility function of this study can be written as follows:

$U_{(T J-A M)}=\beta_{0}+\beta_{1}($ SAVINGFARE $)+\beta_{2}($ SAVINGTIME $)+\beta_{3}($ EXPTRANS $)+\beta_{4}($ EDU $)$

where $U_{(T J-A M)}$ is utility of transjakarta-choice, $X_{i} \ldots X_{n}$ is the product variables observed, $\beta_{0}$ is the alternative specific constant (ASC) and $\beta_{1}-\beta_{n}$ is the coefficient of variables.

\section{Data and analysis}

The first step to analyze the data is by presenting the survey data. The data of stated-preference survey is showed as follows :

\subsection{Proportion Respondent}

Total respondents that have been surveyed is 92 respondents with the following details :

Table 2. The Proportion of respondents' mode

\begin{tabular}{|c|c|}
\hline Mode & Percentage \\
\hline Motorcycle & $62 \%$ \\
\hline Kopaja & $38 \%$ \\
\hline
\end{tabular}

Table 3. The proportion of respondents' gender

\begin{tabular}{|c|c|}
\hline Gender & Percentage \\
\hline Female & $53 \%$ \\
\hline Male & $47 \%$ \\
\hline
\end{tabular}

Table 4. The distribution of respondents' age

\begin{tabular}{|c|c|}
\hline Age Group & Percentage \\
\hline $15-20$ years old & $14 \%$ \\
\hline $21-29$ years old & $53 \%$ \\
\hline $30-39$ years old & $20 \%$ \\
\hline $40-49$ years old & $9 \%$ \\
\hline$>50$ years old & $4 \%$ \\
\hline
\end{tabular}

Table 5. The Proportion of respondents' occupation

\begin{tabular}{|c|c|}
\hline Occupation & Percentage \\
\hline Student & $27 \%$ \\
\hline Employee & $48 \%$ \\
\hline Teacher/Lecturer & $3 \%$ \\
\hline Others & $22 \%$ \\
\hline
\end{tabular}

Table 6. The distribution of education level

\begin{tabular}{|c|c|}
\hline Education Level & Percentage \\
\hline High School & $40 \%$ \\
\hline Diploma & $30 \%$ \\
\hline Bachelor & $11 \%$ \\
\hline Master & $19 \%$ \\
\hline
\end{tabular}


Table 7. The distribution of respondents' transportation expenditure per week

\begin{tabular}{|c|c|}
\hline $\begin{array}{c}\text { Expenditure of } \\
\text { Transportation }\end{array}$ & Percentage \\
\hline$<\mathrm{Rp} 100.000$ & $20 \%$ \\
\hline $\mathrm{Rp} 100.001-\mathrm{Rp} 250.000$ & $49 \%$ \\
\hline $\mathrm{Rp} 250.001-\mathrm{Rp} 500.000$ & $21 \%$ \\
\hline $\mathrm{Rp} 500.001-\mathrm{Rp} 1.000 .000$ & $7 \%$ \\
\hline$>\mathrm{Rp} 1.000 .001$ & $3 \%$ \\
\hline
\end{tabular}

Table 8. The distribution of respondents' expenditure

\begin{tabular}{|c|c|}
\hline Expenditure & Percentage \\
\hline$<\mathrm{Rp} \mathrm{500.000}$ & $3 \%$ \\
\hline $\mathrm{Rp} \mathrm{500.001-Rp} \mathrm{1.000.000}$ & $6 \%$ \\
\hline $\mathrm{Rp} 1.000 .001-\mathrm{Rp} \mathrm{5.000.000}$ & $56 \%$ \\
\hline $\mathrm{Rp} 5.000 .001-\mathrm{Rp}$ & $20 \%$ \\
10.000 .000 & \\
\hline$>\operatorname{Rp~} 10.000 .001$ & $15 \%$ \\
\hline
\end{tabular}

Table 9. The distribution of respondents' main trip distance

\begin{tabular}{|c|c|}
\hline $\begin{array}{c}\text { Main Trip Distance } \\
\text { (KRL's Trip) }\end{array}$ & Percentage \\
\hline $50 \mathrm{Km}$ & $19 \%$ \\
\hline $40 \mathrm{Km}$ & $6 \%$ \\
\hline $35-30 \mathrm{Km}$ & $19 \%$ \\
\hline $25 \mathrm{Km}$ & $56 \%$ \\
\hline
\end{tabular}

\subsection{Model and analysis}

$\mathrm{R}$ programming is used as a tool to build a modal choice model (binomial logit) between Transjakarta motorcycle and Transjakarta - kopaja. After the data was run by $\mathrm{R}$ programming, the model obtained as follows:

Table 10. Summary of models

\begin{tabular}{|c|c|c|c|c|c|c|c|}
\hline \multicolumn{8}{|c|}{ Transjakarta - Motorcycle } \\
\hline No & Variables & Koef & Std. Error & T Value & $\operatorname{Pr}(>)$ & Sig & Log Likelihood \\
\hline 1. & $\overline{\mathrm{ASC}}$ & -0.5578 & $4.910 \mathrm{e}-01$ & -1.136 & 0.25593 & & \multirow{5}{*}{-266.8975} \\
\hline 2. & Savingfare & $-6.353 e-05$ & $2.439 \mathrm{e}-05$ & -2.605 & 0.00920 & $* *$ & \\
\hline 3. & Exp-trans & $2.028 \mathrm{e}-01$ & $8.00 \mathrm{e}-02$ & 2.535 & 0.01123 & $*$ & \\
\hline 4. & Education & $-1.486 \mathrm{e}-01$ & $4.576 \mathrm{e}-02$ & -3.247 & 0.00116 & ** & \\
\hline 5. & savingtime & $-3.065 e-03$ & $1.392 \mathrm{e}-02$ & 0.220 & 0.82581 & & \\
\hline \multicolumn{8}{|c|}{ Transjakarta - Kopaja } \\
\hline No & \begin{tabular}{|l|l|} 
Variables \\
\end{tabular} & Koef & Std.Error & T value & $\operatorname{Pr}(>)$ & Sign & Log Likelihood \\
\hline 1. & $\overline{\mathrm{ASC}}$ & 1.769 & $3.692 \mathrm{e}-01$ & 4.791 & $1.66 \mathrm{e}-06$ & $* *$ & \multirow{5}{*}{-99.63882} \\
\hline 2. & Savingfare & $-6.895 e-05$ & $2.202 \mathrm{e}-05$ & -3.131 & 0.00174 & $* *$ & \\
\hline 3. & Exp-trans & $-9.626 \mathrm{e}-01$ & $1.579 \mathrm{e}-01$ & -6.095 & $1.09 \mathrm{e}-09$ & $* * *$ & \\
\hline 4. & Education & $5.136 \mathrm{e}-01$ & $1.173 \mathrm{e}-02$ & 4.378 & $1.20 \mathrm{e}-05$ & $* * *$ & \\
\hline 5. & Savingtime & $-1.973 e-02$ & $1.737 \mathrm{e}-02$ & -1.136 & 0.25609 & & \\
\hline
\end{tabular}

Based on the model as shown in table 3, the utility function can be arranged as follows:

Table 11. The utility function of transjakarta

\begin{tabular}{|c|c|l|}
\hline No & Mode & \multicolumn{1}{c|}{ Utility Function } \\
\hline 1. & Motorcycle & $\begin{array}{l}\mathrm{U}=-0.5578-0.00006353 \\
\text { (Savingfare) }+0.2018(\text { Exptrans })-0.1486 \\
(\text { Education })-0.003065 \text { (Savingtime })\end{array}$ \\
\hline 2. & Kopaja & $\begin{array}{l}\mathrm{U}=1.769-0.00006895 \text { (Savingfare) }-0.9626 \\
(\text { Exptrans })+0.5136(\text { Education })-0.01973 \\
(\text { Savingtime })\end{array}$ \\
\hline
\end{tabular}

In the model result, there is a positive and negative sign that can be interpreted as follows:

1. The ASC (alternative specific constant) from motorcycle has a negative value. It means that there is a negative chance on the possibility of people to shift from motorcycle to transjakarta without any other influences. While the bus model has a positive value which means that there is such a positive chance that people will shift from bus to transjakarta without any other influences.

2. The variable of saving fare showed both motorcycle and bus have a negative value. It can be interpreted that if the tariff difference between Transjakarta and motorcycle has a negative value or Transjakarta's tariff is cheaper than motorcycle automatically the utility value will be higher so that the probability of shifting to Transjakarta is bigger.

3. The variable of saving time is negative sign which means that if the transjakarta travel time is faster than the existing mode (the saving time is negative) then the probability to shift is increasing. While if the existing modes is faster then it reduces the probability to shift.

While the other socio-economic variables like expenditure of transportation and education showed an opposite result. The result can be influenced by the data distribution.

\subsection{The sensitivity of model}

Sensitivity of model towards tariff change represents how influential the tariff changes to the probability of mode shifting from bus or motorcycle to Transjakarta. The sensitivity of model is represented in graphic so that the probability changes can be observed along with the gradually tariff changes.

The value on horizontal axis represented the $T_{T J}-T_{B u s}$. The negative value showed the condition that using Transjakarta is cheaper than the bus while the positive value pointed the condition when using Transjakarta is more expensive than kopaja.

The graphic showed the comparison of tariff changes towards probability people to shift from each mode, motorcycle and bus. The slope of the lines on the graph tend to negative values, it is stated that the higher the saving fare, the smaller the probability of choosing transjakarta. As seen on the graphic, the slope of bus line is steeper than the motorcycle. It indicated that a little 
change in the fares in model will cause significant changed in the probability of modal choice.

Graphic 1. Model Sensitivity Graphic towards Tariff Changes for Both Motorcycle and Kopaja

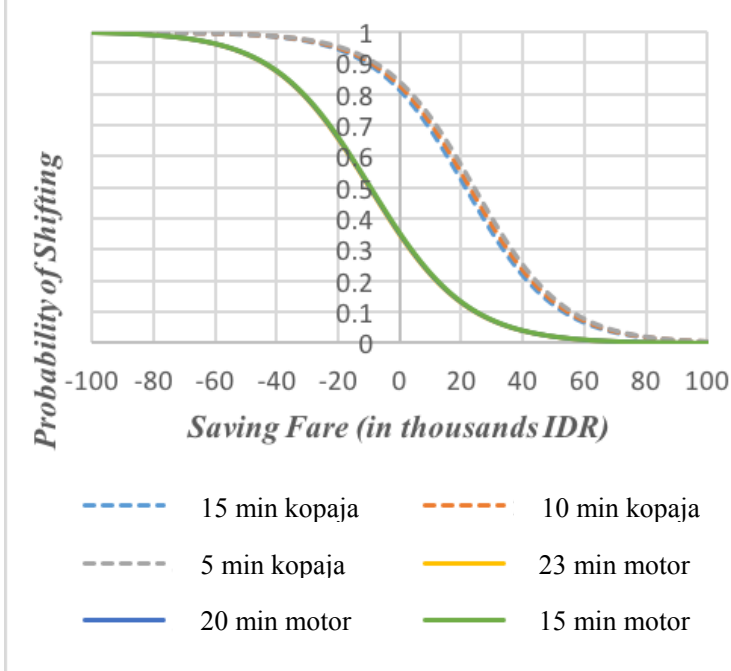

\subsection{Willingness-to-Pay}

Willingness to Pay (WTP) value is a tariff that is willing to be paid by users in the KRL and Transjakarta tariff integration system. The value of WTP can be obtained when probability of each individual in choosing each mode is $50 \%$ while the difference of utility values between HST and other modes equal zero (0).

Table 12. Summary of willingness to pay

\begin{tabular}{|c|c|c|}
\hline $\begin{array}{c}\text { Comparison } \\
\text { Mode }\end{array}$ & $\begin{array}{c}\text { Saving Time } \\
\text { (Ttransjakarta - Tother } \\
\text { modes) }\end{array}$ & $\begin{array}{c}\text { Savingfare at the 0.5 } \\
\text { probability }\end{array}$ \\
\hline Kopaja (Bus) & 15 & Rp 21.364,- \\
\hline Motorcycle & 15 & $(-)$ Rp 9.503,- \\
\hline
\end{tabular}

From the table above we can see that the kopaja users are willing to pay $\mathrm{Rp} 21.364,-$ higher than the existing fares to the system of tariff integration. The number seems like impossible but there are some reasons that might create the result. Firstly, the $(+)$ sign of ASC represent the desire of bus users that is more likely to use transjakarta. On other hand, the existing tariff between transjakarta and the kopaja is not too much different but based on stated preference survey, the respondents stated that the far walking distance from the railway station to the bus stop is the main excuse so they do not use transjakarta.

While for the motorcycle, the users are willing to pay Rp 9.503,- cheaper to shift to transjakarta. The respondents describe that based on safety and comfort, transjakarta is superior than motorcycle but from the efficiency they choose motorcycle. Thus, they only willing to pay Rp 9.503 cheaper to shift to transjakarta.

At the end, revealed survey is also conducted to see the exact number respondents are willing to pay for the tariff integration system. This following table shows the result:
Table 13. The summary of revealed preference survey

\begin{tabular}{|l|l|l|l|l|l|}
\hline \multirow{2}{*}{ Modes } & \multicolumn{6}{|l|}{ Desirable Willingness to Pay } \\
\cline { 2 - 6 } & Average & $\begin{array}{l}\mathbf{7 5}^{\text {th }} \\
\text { percentile }\end{array}$ & Median & STDev & $\begin{array}{l}\text { Max } \\
\text { Tariff }\end{array}$ \\
\hline Kopaja & $\mathrm{Rp}$ & $\mathrm{Rp}$ & $\mathrm{Rp}$ & $\mathrm{Rp}$ & $\mathrm{Rp}$ \\
& $6,250,-$ & $7,500,-$ & $6,000,-$ & $2,098,-$ & $10,000,-$ \\
\hline Motor & $\mathrm{Rp}$ & $\mathrm{Rp}$ & $\mathrm{Rp}$ & $\mathrm{Rp}$ & $\mathrm{Rp}$ \\
cycle & $6,403,-$ & $7,375,-$ & $6,000,-$ & $2,022,-$ & $15,000,-$ \\
\hline All & Rp & $\mathrm{Rp}$ & $\mathrm{Rp}$ & $\mathrm{Rp}$ & $\mathrm{Rp}$ \\
& $\mathbf{6 , 5 5 5 , -}$ & $7,500,-$ & $6,000,-$ & $2,242,-$ & $15,000,-$ \\
\hline
\end{tabular}

According to the table, the respondents are willing to pay $\mathrm{Rp} 6,555,-$ to use the services of KRL and transjakarta as an integrated public transportation system.

\subsection{Potential impacts of tariff integration}

Jakarta as the capital city of Indonesia now is having a huge development and revamping of public transportation. The development starts from the infrastructure construction to the system improvement. The governor of Jakarta is now having a program called 'oktrip'. It is a program that allow people to pay a certain amount of money for using public transportation.

This study can be a reference for the governor to decide the capping system. The number of $\mathrm{Rp} 6.555$,might be representative as the tariff for integrated public transporatation system in Jakarta. Soon, when the policy is implemented, it is expected to create a lot of people to shift to use transjakarta and KRL. In the future, this research could be continued to analyze the additional demand of transjakarta due to tariff integration system.

\section{Conclusion and future research}

This paper investigated the public preference of tariff integration for KRL and Transjakarta locating in the downtown of Jakarta, Sudirman Station as a case study. The research showed that people tend to shift to transjakarta would be influenced by some variables, such as saving fare, saving time, expenditure of transportation, and education. This study focuses to the measured variables such as saving fare and saving time. The result shows that the more negative saving fare or the cheaper transjakarta tariff would be increasing the probability to shift to transjakarta while the more negative saving time or the faster transjakarta also increasing the probability to shift to transjakarta.

The research also clearly showed that there is different tariff preference between motorcycle and kopaja. Based on stated preference survey, kopaja tends to shift to transjakarta with higher fares than motorcycle. Kopaja users are willing to pay $\mathrm{Rp} 21,364,-$ higher to the system of tariff integration while motorcycle users only willing to shift if the tariff integration is Rp 9,503,- cheaper than the existing tariff. This different result is caused by different existing condition of each modes where kopaja tariff and travel time are not much different with transjakarta's while motorcycle tariff is way higher with faster travel time. At the end of the survey, respondents 
also asked their exact preference tariff for this integration system. This revealed survey produced that averagely the respondents are willing to pay $\mathrm{Rp} 6,555$,- for this KRL and Transjakarta tariff integration system.

The outcome of this study particularly has great potential impact on the program created by Jakarta government. Despite reducing the transportation cost, this study provide the exact number of how much the people of Jakarta are willing to pay to the tariff integration system. This result is expected to be the reference of Jakarta government in order to decide the public policy related with the famous program called 'oktrip'.

The result of this study suggested that tariff integration system should be implemented as the first step of public transportation improvement. Further research is required to examine the additional demand due to the implementation of tariff integration system.

\section{Acknowledgement}

This study is funded by Universitas Indonesia under the PITTA scheme No: 2376/UN.R3.1/HKP.05.00/2018. This fund is very useful for developing research both for the authors and the institution.

\section{References}

1. Fitrianingsih, \& Paramitarani. (2004). Kesediaan dan Kemampuan Penumpang Kereta Api "Pandawangi". Universitas Katolik Soegijapranata, Semarang.

2. Leland Blank, Anthony Tarquin. (2012). The McGraw-Hill Companies. New York: Raghothaman Srinivasan.

3. Lembaga Teknologi Fakultas Teknik. (2017). Laporan Akhir Studi Travel Diaries Penumpang LRT
Jabodetabek . Jakarta, DKI Jakarta: Universitas Indonesia.

4. Lembaga Teknologi Fakultas Teknik Universitas Indonesia. (2017). Laporan Akhir Studi Willingness to Pay Penumpang LRT Jabodetabek. Jakarta, DKI Jakarta: Universitas Indonesia.

5. Manning, C. (2007). Logistics Regression (with R). Stanford: Stanford University.

6. McFadden, D. (1997). Measuring Willingness-ToPay For Transportation Improvement .

7. Ortuzar, J. d., \& Willumsem, L. G. (2011). Modelling Transport. WILEY.

8. Prabhakaran, S. (2016). Retrieved November 23, 2017, from r-statistics.co: http://rstatistics.co/Logistic-Regression-With-R.html

9. Sharaby, N., \& Shiftan, Y. (2012). The Impact of Fare Integration on Travel Behavior and Transit Ridership . Elsevier, 63-70.

10. Badan Pusat Statistik. (2016). Statistik Transportasi DKI Jakarta . Jakarta, DKI Jakarta: Badan Pusat Statistik DKI Jakarta.

11. Breidert, C. (2005). Estimation of Willingness-to-Pay. Theory, measurement, and application. Vienna University of Economics and Business, Vienna.

12. Sihombing, D. A., \& Surbakti, M. S. (2010). Analisa Pemilihan Moda Kereta Api dan Bus (Studi Kasus: Medan - Pematang Siantar). Departemen Teknik Sipil. Medan: Universitas Sumatera Utara.

13. Tamin, R. O., H., K., Munandar, A., \& Setiadji, B. (1999). Studi Evaluasi Tarif Angkutan Umum dan Analisa Ability to Pay (ATP) dan Willingness to Pay (WTP) di DKI Jakarta. Jurnal Transportasi , 1, 122135.

14. Torres-Reyna, O. (2014). Logit, Probit, and Multinomial Models in $R$. Princeton: Princeton University. 